\title{
IGF2 Gene Variants and Risk of Hypertension in Obese Children and Adolescents
}

\author{
MARIA F. FAIENZA, NICOLA SANTORO, ROSARIA LAUCIELLO, RAFFAELE CALABRÒ, LUCIA GIORDANI, \\ GIOVANNI DI SALVO, ANNAMARIA VENTURA, MAURIZIO DELVECCHIO, LAURA PERRONE, \\ EMANUELE M. DEL GIUDICE, AND LUCIANO CAVALLO
}

\author{
Department of Biomedicine of Developmental Age [M.F.F., R.L., L.G., A.V., M.D., L.C.], University of Bari, Bari 70124, Italy; \\ Departments of Pediatrics "F. Fede" [N.S., L.P., E.M.G.], and Cardiology [R.C., G.S.], Second University of Napoli, Napoli 80131, Italy
}

\begin{abstract}
Obese children have a great risk of hypertension and cardiovascular morbidity in adults. The insulin-like growth factor type II (IGF-II) regulates glucose homeostasis, cardiovascular functions, and lipid metabolism. IGF2 gene variants have shown a strong association with weight, body mass index (BMI), and metabolic profile in adults. We performed the molecular screening of two IGF2 polymorphisms (6815 A/T, $820 \mathrm{G} / \mathrm{A})$, in 227 obese children to evaluate the potential association between $I G F 2$ variants with either obesity or high blood pressure (assessed with a 24-h holter system) or both. A second cohort of age-, sex-, and BMI-matched children were enrolled to confirm any eventual association. We observed a significant association between the $6815 \mathrm{~A} / \mathrm{T} I G F 2$ gene variant and high systolic blood pressure in obese children. Homozygote subjects for the T6815 allele showed, even in 24-h measurements, a higher risk to develop hypertension than those carrying the A6815 allele (OR = 3.7, 95\% CI: 1.59-8.66). This result was confirmed in the second cohort $(\mathrm{OR}=4.1,95 \% \mathrm{CI}: 1.41-6.50)$. Any statistically significant difference in terms of BMI between the genotype groups was observed. Our results suggest that $I G F 2$ gene variants are involved in the blood pressure regulation in obese children. (Pediatr Res 67: 340-344, 2010)
\end{abstract}

$\mathrm{O}$ besity has become an increasingly important medical condition in children and adolescents. Many metabolic and cardiovascular complications associated with obesity, previously thought to be adult diseases, are now affecting children too.

Together with the increasing prevalence of obesity, primary hypertension has become more common in children than secondary hypertension (1). Obese children run a 4.5- and 2.4-fold greater risk of high systolic and diastolic blood pressure than nonobese children, and hypertension in childhood represents the major risk factor for cardiovascular morbidity and mortality in adults $(1,2)$.

Determination of body weight and composition, blood pressure, and plasma triglycerides is multifactorial, both genetic and environmental factors contributing to it. A large number of genes, markers, and chromosomal regions have been asso-

Received December 3, 2009; accepted December 4, 2009

Correspondence: Maria Felicia Faienza, M.D., Ph.D., Department of Biomedicine of Developmental Age, University of BariPiazza G. Cesare, 11, 70100 Bari, Italy; e-mail: mf.faienza@endobiomol.uniba.it ciated with human obesity phenotype (3-5), essential hypertension (6-9), and high plasma TG levels (10).

Insulin-like growth factors type I (IGF-I) and type II (IGFII), besides their major function in growth and cell differentiation, play a role in regulating glucose homeostasis, cardiovascular functions, and lipid metabolism $(11,12)$.

In particular, the insulin-like growth factor 2 (IGF2) gene is candidate for association with obesity (13-16). This imprinted gene lies in close proximity to the insulin and tyrosine hydroxylase genes on chromosome $11 \mathrm{p} 15$, in a genomic region related to regulation of both body weight and cardiovascular risk (15,17-19). Moreover, a recent study conducted on Prague hypertriglyceridemic rats demonstrated a possible important role of $I G F 2$ gene in lipid metabolism and blood pressure regulation (20). At least four polymorphisms within the IGF2 gene have shown a strong association with body weight, body mass index (BMI), and related metabolic changes in adult men $(13,14,21)$. One of these variants, the $820 \mathrm{G} / \mathrm{A}$ (ApaI), has also been associated with circulating concentrations of the hormone.

Considering that $I G F 2$ gene variants have a role in regulating body weight and metabolic profile and the lack of data in childhood obesity, we decided to screen two IGF2 single nucleotide polymorphisms (SNPs), the $6815 \mathrm{~A} / \mathrm{T}$ in the P1 promoter region and the $820 \mathrm{G} / \mathrm{A}(A p a \mathrm{I})$ in the untranslated region ( $3^{\prime} \mathrm{UTR}$ ) of exon 9 , in a population of obese children and adolescents to evaluate the potential association between variants of this gene with either obesity or high blood pressure (assessed with a 24-h holter system) or both.

\section{METHODS}

This study has been approved by Review Board of Department of Pediatrics "F. Fede", Second University of Naples, Naples, Italy. ${ }^{1}$

Subjects. Two independently recruited cohorts of obese children and adolescents were included in the study. The first cohort was composed by 227 subjects ( 128 girls; mean age $10.5 \pm 2.9$ y) recruited from 2005 to the end of 2006 at the Department of Pediatrics of the Second University of Naples. A second cohort composed by 200 obese subjects referred at the same depart-

Abbreviations: ABPM, ambulatory blood pressure monitoring; SNPs, single nucleotide polymorphisms; TG, triglycerides 
ment from February to September 2009 (86 girls; mean age $10.4 \pm 3.0$ y). Only subjects referred for the first time to our department, who were not under therapy for hypertension, were enrolled in the study. A control population of 200 subjects having normal weight for height (lean controls) (100 girls; mean age $10.3 \pm 2.8 \mathrm{y}$ ) were enrolled in the study. The control population was chosen as previously described (22). Pubertal stage was evaluated according to Tanner staging (23).

Measurements. Height was measured with a wall mounted Harpender stadiometer and SD scores for height were calculated according to Tanner and Whitehouse (23). Weight measure was performed with subjects in minimal clothes, with a scale accurate to the nearest $0.1 \mathrm{~kg}$. BMI was calculated as weight in kilograms divided by the square of height in meters. Obesity was defined as BMI exceeding the 95th percentile for sex and age according to reference values, and the deviation from the mean reference value was evaluated by calculating the SD scores ( $z$-scores) (24).

Protocol and data analysis. All obese patients underwent an ambulatory blood pressure monitoring (ABPM) measurement. Systolic blood pressure (SBP) and diastolic blood pressure (DBP) were measured three times while the subjects were seated and the two last measurements were averaged for the analysis. A SpaceLabs model 90207 monitor (SpaceLabs, Inc., Redmond, WA) weighing $340 \mathrm{~g}$ (including batteries) was used for ABPM. This device uses an oscillometric method with a deflation rate of $8 \mathrm{~mm} \mathrm{Hg} / \mathrm{s}$. The proper cuff was selected from among three sizes supplied by the manufacturer $(103$ 13,13324 , and $24332 \mathrm{~cm}$ ) according to the arm length of the subject. The cuff wrapped completely around the nondominant upper arm with the bladder covering at least two-third of it. The device was checked against a mercury sphygmomanometer by a Y-tube. Ambulatory blood pressure monitoring was performed on regular school days with normal recreational activities. SDs according to height were calculated for systolic and diastolic 24-h mean values and for day-time and night-time means by using as reference the LMS method according to Wuhl et al. (25). Hypertension in ABPM was defined as mean systolic or mean diastolic 24-h blood pressure higher than 95th percentile adjusted for height (25).

After informed consent, genomic DNA was collected from nucleated white blood cells of all subjects. Samples were obtained anonymously from controls undergoing routine analysis. The two IGF2 gene SNPs, 6815A/T (rs3842759) at nucleotide position 6815 in the GenBank sequence L15440 and 820 G/A (ApaI, rs680) at nucleotide position 820 in the GenBank sequence X07868, were PCR amplified. Genotype screening of the amplicons was performed by denaturing HPLC (DHPLC) on a WAVE ${ }^{\mathrm{TM}}$ MD 4000 plusTM DNA fragment Analysis System (Transgenomic, Inc., Omaha, NE). PCR products were analyzed alone and mixed in approximately equimolar proportions with an amplified sample known to contain a GG genotype for 820 G/A polymorphism and AA genotype for $6815 \mathrm{~A} / \mathrm{T}$ polymorphism, then denatured at $94^{\circ} \mathrm{C}$ for $5 \mathrm{~min}$ and cooled at room temperature, to allow heteroduplex formation. Samples with or without an altered chromatographic profile were randomly chosen to be sequenced. Direct sequencing was performed after purifying PCR products with QIAquick PCR purification kit (QIAGEN, Hilden, Germany). Both strands were sequenced using the BigDye Terminator v3.1 Cycle Sequencing Kit (Applied Biosystems, Foster City, CA) and analyzed on an ABI PRISM 310 automated sequencers (Applied Biosystem, Foster City, $\mathrm{CA}$ ). Sequences were analyzed by the Sequencing Analysis 3.4 version software.

A $\chi^{2}$ test was generated to evaluate the linkage disequilibrium and to test the differences of genotypes and allele frequency. Hardy-Weinberg equilibrium test was applied on the nonobese and obese children separately. In the population of obese children, genotypes features were compared by using a general linear model. A multivariate analysis was used to evaluate the effect of the genotype on SBP and DBP singularly and the interaction between genotype and gender or pubertal status. Along with the interaction terms, the model included age, BMI, and height. A logistic regression was used to calculate the odds of obese subjects developing hypertension according to the genotype. Although raw values are shown, nonnormally distributed variables were $\log$-transformed before analyzing them. Data are expressed as mean and SDs. A $p$ value $<0.05$ was considered statistically significant.

\section{RESULTS}

One hundred eighteen obese subjects $(53.6 \%, 58$ girls) in the first cohort, 104 obese subjects in the second cohort (52\%, 47 girls), and 115 lean controls $(57.5 \%, 61$ girls) were prepubertal $(p=0.8)$. Obese children showed higher values of systolic and diastolic blood pressure than lean subjects $(p<$ 0.001). Among obese children, 49 (30 females; 22 prepuber- tal) showed a mean systolic or mean diastolic 24-h blood pressure higher than 95th percentile adjusted for height.

With regard to the $6815 \mathrm{~A} / \mathrm{T} \mathrm{SNP}$, the A allele frequency was 0.61 (cohort 1 ) and 0.53 (cohort 2) in obese and 0.54 in controls ( $p=0.5$ and 0.9 , respectively), whereas the T allele frequency in obese subjects was 0.39 (cohort 1) and 0.57 (cohort 2) and 0.46 in controls ( $p=0.5$ and 0.1 , respectively). In addition, the genotype distribution was similar in obese and controls (obese: AA 42\%, AT 43\%, TT 15\%; controls: AA $34 \%$, AT $44 \%$, TT $22 \% ; p=0.2$ ). Allele frequencies were in Hardy-Weinberg equilibrium in all the populations (both $p>0.1$ ).

Clinical features of obese subjects were compared according to IGF2 genotypes (Table 1). When the clinical features of obese children were evaluated according to the genotype, the three groups of genotype differed only for the systolic blood pressure (AA: $112.5 \pm 11.6$, AT: $114 \pm 10.6$, TT: $119 \pm$ $15.3 ; p=0.007)$. Although the same trend was observed, there were no statistically significant differences in diastolic blood pressure (AA: $64.4 \pm 9.3$, AT: $65.4 \pm 9.2,67.2 \pm 10.7$; $p=0.3$ ). This observation was also confirmed by comparing the 24-h blood pressure values between the three groups of genotypes (Table 1). The evaluation performed in the second group of obese subjects confirmed and corroborated this observation (Table 2). Because differences in gender and pubertal status may influence changes in blood pressure, a multivariate analysis was performed separately in the two cohorts to assess whether there was an interaction between puberty and/or gender with the genotype. There was no interaction between genotype and gender or pubertal status in both cohorts (cohort 1: genotype $\times$ pubertal status, $p=0.09$; genotype $\times$ gender, $p=0.2$; cohort 2: genotype $\times$ pubertal status, $p=0.4$; genotype $\times$ gender, $p=0.4$ ). The association between the studied polymorphism and blood pressure was not seen in lean controls (Table 3).

Moreover, homozygote subjects for the rare allele showed a higher risk to develop hypertension than subjects carrying the other genotypes. In particular, $20 \mathrm{~A} / \mathrm{A}(21 \%), 20$ heterozygotes $(20 \%)$, and $18 \mathrm{~T}$ allele (50\%) homozygotes were hypertensive $\left(\chi^{2} 11.1, p=0.003\right.$; OR $\left.=3.7,95 \% \mathrm{CI}: 1.59-8.66\right)$ (Fig. 1A). The same result was obtained in the second population of obese subjects $\left(\chi^{2} 14.3, p=0.001 ; \mathrm{OR}=4.1 ; 95 \%\right.$ CI: 1.41-6.50) (Fig. 1B). No other differences between the $I G F 2$ genotypes were observed.

Concerning the $820 \mathrm{G} / \mathrm{A}$ (ApaI) polymorphism of the obese subjects, $45.2 \%$ were $\mathrm{G}$ homozygotes, $39.5 \%$ were heterozygotes, and $15.3 \%$ were A homozygotes, whereas among lean controls, $46.7 \%$ were $\mathrm{G}$ homozygotes, $48.9 \%$ were heterozygotes, and $5 \%$ were A homozygotes $(p=0.07)$. The $\mathrm{G}$ allele frequency was 0.65 in obese and 0.71 in lean controls $(p=$ 0.6 ), whereas the A allele frequency was 0.35 in obese subjects and 0.29 in controls $(p=0.4)$. No association between the $820 \mathrm{G} / \mathrm{A}(A p a \mathrm{I})$ polymorphism and blood pressure was observed for both systolic (AA: $114.9 \pm 15.6$, AT: $116.1 \pm$ 13.9, TT: $115 \pm 18.3 ; p=0.1)$ and diastolic blood pressure (AA: $66.1 \pm 11.9$, AT: $65.6 \pm 13.1,65.5 \pm 15.1 ; p=0.3$ ). This observation was also confirmed by comparing the $24-\mathrm{h}$ 
Table 1. Comparison of the clinical features according to the three different IGF2 genotypes obtained by general linear model

\begin{tabular}{|c|c|c|c|c|}
\hline & A/A (95) & A/T (96) & $\mathrm{T} / \mathrm{T}(36)$ & $p$ \\
\hline Age (y) & $10.6 \pm 2.9$ & $10.3 \pm 3.1$ & $10.8 \pm 2.4$ & 0.5 \\
\hline Sex $(\%$ females $) *$ & 46 & 51 & 51 & 0.4 \\
\hline Prepubertal $(\%)^{*}$ & 38 & 52 & 36 & 0.08 \\
\hline Height (SD scores) & $0.1 \pm 2.5$ & $0.2 \pm 2.9$ & $0.5 \pm 2.7$ & 0.8 \\
\hline $\operatorname{BMI}\left(\mathrm{kg} / \mathrm{m}^{2}\right)$ & $30.0 \pm 4.7$ & $29.3 \pm 4.7$ & $30.7 \pm 5.5$ & 0.4 \\
\hline$z$-score BMI & $3.4 \pm 2.2$ & $3.3 \pm 1.6$ & $3.9 \pm 2.8$ & 0.5 \\
\hline SBP office $(\mathrm{mm} \mathrm{Hg}) \dagger$ & $112.5 \pm 11.6$ & $114 \pm 10.6$ & $119 \pm 15.3$ & 0.007 \\
\hline DBP office $(\mathrm{mm} \mathrm{Hg}) \dagger$ & $64.4 \pm 9.3$ & $65.4 \pm 9.2$ & $67.2 \pm 10.7$ & 0.3 \\
\hline 24-h SBP $(\mathrm{mm} \mathrm{Hg}) \dagger$ & $110.4 \pm 18.8$ & $112.0 \pm 16.9$ & $119.4 \pm 26.3$ & 0.03 \\
\hline 24-h SBP (SD scores) & $0.6 \pm 0.5$ & $0.5 \pm 0.7$ & $1.2 \pm 1.2$ & $<0.001$ \\
\hline 24-h DBP $(\mathrm{mm} \mathrm{Hg}) \dagger$ & $55.2 \pm 14.7$ & $55.2 \pm 15.7$ & $59.0 \pm 17.3$ & 0.09 \\
\hline 24-h DBP (SD scores) $\ddagger$ & $0.3 \pm 1.1$ & $0.3 \pm 0.6$ & $0.6 \pm 1.0$ & 0.05 \\
\hline 24-h MAP $(\mathrm{mm} \mathrm{Hg}) \dagger$ & $74.9 \pm 12.5$ & $74.0 \pm 13.9$ & $80.0 \pm 10.1$ & 0.2 \\
\hline 24-h MAP (SD scores) & $0.6 \pm 0.8$ & $0.8 \pm 1.0$ & $1.1 \pm 1.0$ & 0.06 \\
\hline Day SBP $(\mathrm{mm} \mathrm{Hg}) \dagger$ & $115.2 \pm 20.2$ & $114.8 \pm 18.4$ & $122.2 \pm 15.6$ & 0.04 \\
\hline Day SBP (SD scores) & $0.7 \pm 1.3$ & $0.9 \pm 1.1$ & $1.3 \pm 0.9$ & 0.01 \\
\hline Day DBP $(\mathrm{mm} \mathrm{Hg}) \dagger$ & $62.7 \pm 26.1$ & $61.7 \pm 29.3$ & $67.0 \pm 32.2$ & 0.5 \\
\hline Day DBP (SD scores) & $0.2 \pm 0.8$ & $0.3 \pm 0.9$ & $0.5 \pm 0.9$ & 0.3 \\
\hline MAP day $(\mathrm{mm} \mathrm{Hg}) \dagger$ & $78.0 \pm 17.6$ & $77.5 \pm 20.2$ & $82.7 \pm 15.2$ & 0.04 \\
\hline MAP day (SD scores) & $0.7 \pm 0.8$ & $0.8 \pm 1.0$ & $1.1 \pm 1.0$ & 0.05 \\
\hline Night SBP $(\mathrm{mm} \mathrm{Hg}) \dagger$ & $104.1 \pm 15.9$ & $105.6 \pm 16.8$ & $114 \pm 27.0$ & 0.03 \\
\hline Night SBP (SD scores) & $0.3 \pm 0.3$ & $0.4 \pm 0.4$ & $0.6 \pm 0.5$ & 0.02 \\
\hline Night DBP $(\mathrm{mm} \mathrm{Hg}) \dagger$ & $45.0 \pm 17.9$ & $42.8 \pm 15.4$ & $47 \pm 13.8$ & 0.09 \\
\hline Night DBP (SD scores) $\dagger$ & $0.2 \pm 0.6$ & $0.2 \pm 0.6$ & $0.4 \pm 0.6$ & 0.4 \\
\hline MAP night $(\mathrm{mm} \mathrm{Hg}) \dagger$ & $65.1 \pm 13.0$ & $65.3 \pm 14.3$ & $71.9 \pm 9.3$ & 0.02 \\
\hline MAP night (SD scores) & $0.2 \pm 0.5$ & $0.3 \pm 0.6$ & $0.7 \pm 0.8$ & 0.008 \\
\hline
\end{tabular}

* Prevalence was compared by a $\chi^{2}$ test.

$\dagger$ Adjusted for age, sex, pubertal stage, height, and BMI.

\$ Nonnormally distributed variables were log-transformed before performing the analysis.

SBP, systolic blood pressure, DBP, diastolic blood pressure, MAP, mean arterial pressure.

Table 2. Comparison of the clinical features according to the three different IGF2 genotypes obtained by general linear model

\begin{tabular}{|c|c|c|c|c|}
\hline & $\mathrm{A} / \mathrm{A}(70)$ & $\mathrm{A} / \mathrm{T}(73)$ & $\mathrm{T} / \mathrm{T}(57)$ & $p$ \\
\hline Age (y) & $10.4 \pm 2.8$ & $10.4 \pm 3.1$ & $10.6 \pm 3.3$ & 0.7 \\
\hline Sex $(\% \text { females })^{*}$ & 42 & 43 & 39 & 0.6 \\
\hline Prepubertal $(\%)^{*}$ & 51 & 55 & 49 & 0.7 \\
\hline Height (SD scores) & $1.44 \pm 0.15$ & $1.43 \pm 0.17$ & $1.43 \pm 0.15$ & 0.1 \\
\hline BMI $\left(\mathrm{kg} / \mathrm{m}^{2}\right)$ & $29.7 \pm 4.2$ & $29.9 \pm 5.5$ & $29.6 \pm 4.9$ & 0.2 \\
\hline$z$-score BMI & $3.1 \pm 2.5$ & $3.3 \pm 2.9$ & $3.1 \pm 2.1$ & 0.6 \\
\hline SBP office $(\mathrm{mm} \mathrm{Hg}) \dagger$ & $110.5 \pm 10.9$ & $115.9 \pm 11.4$ & $116.1 \pm 10.8$ & 0.005 \\
\hline DBP office $(\mathrm{mm} \mathrm{Hg}) \dagger$ & $62.3 \pm 8.7$ & $64.2 \pm 9.3$ & $69.0 \pm 9.7$ & 0.003 \\
\hline 24-h SBP $(\mathrm{mm} \mathrm{Hg}) \dagger$ & $107.4 \pm 38.8$ & $108.0 \pm 26.9$ & $116.0 \pm 36.3$ & 0.05 \\
\hline 24-h SBP (SD scores) & $0.5 \pm 0.5$ & $0.5 \pm 0.6$ & $1.0 \pm 0.8$ & $<0.001$ \\
\hline 24-h DBP $(\mathrm{mm} \mathrm{Hg}) \dagger$ & $54.4 \pm 24.7$ & $54.6 \pm 17.7$ & $58.0 \pm 25.3$ & 0.1 \\
\hline 24-h DBP (SD scores) $\ddagger$ & $0.3 \pm 1.1$ & $0.3 \pm 0.6$ & $0.6 \pm 1.0$ & 0.05 \\
\hline 24-h MAP $(\mathrm{mm} \mathrm{Hg}) \dagger$ & $71 \pm 11.0$ & $73 \pm 20.0$ & $85 \pm 24.3$ & 0.01 \\
\hline 24-h MAP (SD scores) & $0.46 \pm 0.78$ & $0.49 \pm 0.82$ & $1.37 \pm 1.10$ & $<0.0001$ \\
\hline Day SBP $(\mathrm{mm} \mathrm{Hg}) \dagger$ & $113.2 \pm 18.9$ & $116.2 \pm 19.9$ & $129.2 \pm 25.0$ & $<0.0001$ \\
\hline Day SBP (SD scores) & $0.45 \pm 0.50$ & $0.66 \pm 0.65$ & $1.56 \pm 0.82$ & $<0.0001$ \\
\hline Day DBP $(\mathrm{mm} \mathrm{Hg}) \dagger$ & $59.6 \pm 19.1$ & $62.0 \pm 23.9$ & $65.2 \pm 31.1$ & 0.05 \\
\hline Day DBP (SD scores) $\ddagger$ & $0.08 \pm 0.1$ & $0.3 \pm 0.1$ & $0.4 \pm 0.4$ & 0.09 \\
\hline MAP day $(\mathrm{mm} \mathrm{Hg}) \dagger$ & $74 \pm 10.8$ & $74 \pm 11.7$ & $86 \pm 17.2$ & $<0.0001$ \\
\hline MAP day (SD scores) & $0.47 \pm 0.78$ & $0.52 \pm 0.86$ & $1.40 \pm 1.09$ & $<0.0001$ \\
\hline Night SBP $(\mathrm{mm} \mathrm{Hg}) \dagger$ & $102 \pm 21.0$ & $104 \pm 19.3$ & $117 \pm 23.0$ & 0.03 \\
\hline Night SBP (SD scores) & $0.23 \pm 0.26$ & $035 \pm 0.35$ & $0.78 \pm 0.42$ & $<0.0001$ \\
\hline Night DBP $(\mathrm{mm} \mathrm{Hg}) \dagger$ & $40.0 \pm 19.2$ & $42.1 \pm 16.6$ & $43.1 \pm 23.5$ & 0.1 \\
\hline Night DBP (SD scores) $\ddagger$ & $0.09 \pm 0.3$ & $0.22 \pm 0.53$ & $0.25 \pm 0.74$ & 0.3 \\
\hline MAP night $(\mathrm{mm} \mathrm{Hg}) \dagger$ & $60.1 \pm 18.2$ & $64.3 \pm 19.9$ & $70.2 \pm 19.9$ & 0.001 \\
\hline MAP night (SD scores) & $0.07 \pm 0.48$ & $0.25 \pm 0.52$ & $0.67 \pm 0.69$ & $<0.0001$ \\
\hline
\end{tabular}

* Prevalence was compared by a $\chi^{2}$ test.

$\dagger$ Adjusted for age, sex, pubertal stage, height, and BMI.

$\$$ Nonnormally distributed variables were log-transformed before performing the analysis.

SBP, systolic blood pressure, DBP, diastolic blood pressure, MAP, mean arterial pressure. 
Table 3. Comparison of the clinical features according to the three different IGF2 genotypes obtained by general linear model in the control population

\begin{tabular}{|c|c|c|c|c|}
\hline & A/A (68) & $\mathrm{A} / \mathrm{T}(88)$ & $\mathrm{T} / \mathrm{T}(44)$ & $P$ \\
\hline Age (y) & $10.2 \pm 3.2$ & $10.9 \pm 2.3$ & $10.0 \pm 3.3$ & 0.3 \\
\hline Sex $(\% \text { females })^{*}$ & 49 & 51 & 50 & 0.9 \\
\hline Prepubertal $(\%)^{*}$ & 59 & 60 & 56 & 0.8 \\
\hline SD score height & $0.2 \pm 0.21$ & $0.3 \pm 0.27$ & $0.1 \pm 0.49$ & 0.09 \\
\hline BMI $\left(\mathrm{kg} / \mathrm{m}^{2}\right)$ & $18.5 \pm 2.2$ & $18.2 \pm 2.3$ & $17.9 \pm 1.9$ & 0.9 \\
\hline$z$-score BMI & $0.3 \pm 0.7$ & $0.2 \pm 0.9$ & $0.1 \pm 1.1$ & 0.9 \\
\hline SBP office $(\mathrm{mm} \mathrm{Hg}) \dagger$ & $106 \pm 9.3$ & $107 \pm 11.3$ & $105 \pm 7.9$ & 0.5 \\
\hline DBP office $(\mathrm{mm} \mathrm{Hg}) \dagger$ & $58 \pm 13.0$ & $61 \pm 9.4$ & $57 \pm 18.1$ & 0.2 \\
\hline
\end{tabular}

* Prevalence was compared by a $\chi^{2}$ test.

$\dagger$ Adjusted for age, sex, pubertal stage, height, and BMI.

SBP, systolic blood pressure, DBP, diastolic blood pressure.

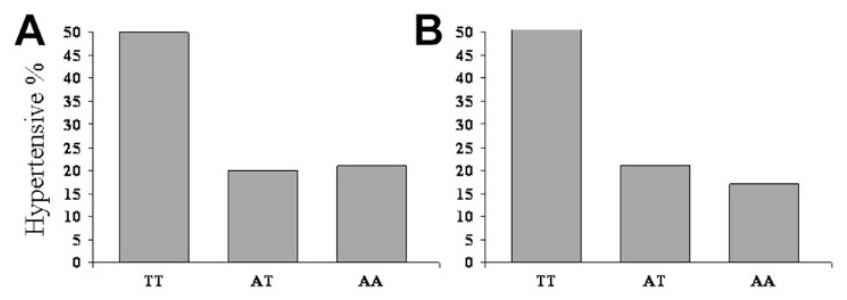

Figure 1. Prevalence of patients with hypertension according to the IGF2 genotypes in cohort $1(A)$ and cohort $2(B)$.

blood pressure values between the three groups of genotypes (data not shown).

None of the two SNPs tested showed significant association with $\mathrm{BMI}(p>0.05)$.

\section{DISCUSSION}

In this study, we observed a significant association between the $6815 \mathrm{~A} / \mathrm{T}$ IGF2 gene variant and high systolic blood pressure, assessed with a 24-h holter system, in obese children and adolescents.

In particular, obese homozygote subjects for the T6815 allele showed, even in 24-h measurements, higher systolic blood pressure than those carrying the A6815 allele. By contrast, we did not observe any difference in $I G F 2$ variant genotype frequencies between lean and obese children and, in the subset of obese children, any statistically significant difference in terms of BMI between the genotype groups.

The hypothesis of a possible influence of IGF2 gene polymorphism on body weight is still being discussed. In previous studies conducted in adult men, three $I G F 2$ polymorphisms were independently associated with BMI $(13,14)$. However, other studies did not confirm this observation $(18,26)$. Furthermore, O'Dell et al. (27) did not find an association between IGF2 ApaI polymorphism and body weight in their young adult population, but in older subjects (13). The authors therefore hypothesized that the effect of this polymorphism on BMI might occur only later in life, possibly as a consequence of the interaction with environmental factors related to age.

In our study, we did not find a significant association between BMI and the two IGF2 SNPs analyzed, confirming the data reported by other authors $(26,28,29)$, but we found an interesting association between the $6815 \mathrm{~A} / \mathrm{T}$ polymorphism of the promoter region of the IGF2 gene and systolic blood pressure in obese subjects. Specific haplotypes of IGF2INS-TH gene cluster are associated with significantly fat mass and high blood pressure in humans, thus representing cardiovascular risk traits (19). Experiments in Prague hereditary hypertriglyceridemic (HTG) and hypertensive rats confirmed the importance of $I G F 2$ gene for determining metabolic and cardiovascular phenotypes. In particular, polymorphism of IGF2 gene seems to play an important role in lipid metabolism and to be involved in blood pressure regulation through a particular vasoactive system (20).

In addition, the role of IGF-II in the central regulation of neuropeptide $\mathrm{Y}$, a powerful vasoconstrictor peptide, has been demonstrated in vitro (30). Recently, some of us (31) demonstrated that $\mathrm{Y} 2$ receptor gene variants, encoding the $\mathrm{Y} 2$ receptor subtype binding both the NPY and YY (PPY) peptides, are involved in blood pressure regulation in obese children and adolescents.

A functional role of the $6815 \mathrm{~A} / \mathrm{T}$ polymorphism in the P1 promoter of the IGF2 gene in effecting a conformational change in DNA has been suggested $(14,32,33)$. In fact, as the CCAAT/enhancer binding protein $\alpha(\mathrm{C} / \mathrm{EBP} \alpha)$ has been identified as a major contributor to postnatal liver-specific activation of the human IGF2 $\mathrm{P} 1$ promoter (its recognition site being situated $27 \mathrm{bp}$ upstream of $6815 \mathrm{~A} / \mathrm{T}$ ) (34), we hypothesize that the alteration of IGF-II expression resulting from the A-T change could be involve in blood pressure regulation through a particular vasoactive system.

Unfortunately, the lack of data about blood pressure measurements in our cohort of lean subjects does not allows us to understand whether the effect of this variant is present in lean children too or linked to the presence of obesity. On the other hand, according to our results, the early clinical course of hypertension in obesity is initially characterized by a predominance of isolated systolic without diastolic hypertension (1), with elevated nocturnal systolic blood pressure values, and/or attenuation of the physiologic nocturnal blood pressure dip (35).

Thus, even if no correlations were found between the two IGF2 SNPs analyzed and BMI in our obese subjects, the differences between our and previous studies may be ascribed to the different ages of the studied cohorts, our study population being composed of children and adolescents. In other words, an age-dependent effect of $I G F 2$ polymorphisms on body weight may be hypothesized, confirming previous data 
about other examples of gene variants influencing obese phenotype $(31,36)$.

In conclusion, we demonstrated an association between $6815 \mathrm{~A} / \mathrm{T} I G F 2$ gene variant and blood pressure in obese children and adolescents. Because primary hypertension has become increasingly common in association with obesity, and because isolated systolic hypertension has proved to be a major risk factor for cardiovascular morbidity and mortality in adults, further investigation of the causes and interventions for this pattern in obese children is clearly needed.

\section{REFERENCES}

1. Sorof J, Daniels S 2002 Obesity hypertension in children: a problem of epidemic proportions. Hypertension 40:441-447

2. Freedman DS, Dietz WH, Srinivasan SR, Berenson GS 1999 The relation of overweight to cardiovascular risk factors among children and adolescents: the Bogalusa heart study. Pediatrics 103:1175-1182

3. Rankinen T, Zuberi A, Chagnon YC, Weisnagel SJ, Argyropoulos G, Walts B, Pérusse L, Bouchard C 2006 The human obesity gene map: the 2005 update. Obesity (Silver Spring) 14:529-644

4. Dina C 2008 New insights into the genetics of body weight. Curr Opin Clin Nutr Metab Care 11:378-384

5. Thorleifsson G, Walters GB, Gudbjartsson DF, Steinthorsdottir V, Sulem P, Helgadottir A, Styrkarsdottir U, Gretarsdottir S, Thorlacius S, Jonsdottir I, Jonsdottir T, Olafsdottir EJ, Olafsdottir GH, Jonsson T, Jonsson F, Borch-Johnsen K, Hansen T, Andersen G, Jorgensen T, Lauritzen T, Aben KK, Verbeek AL, Roeleveld N, Kampman E, Yanek LR, Becker LC, Tryggvadottir L, Rafnar T, Becker DM, Gulcher J, Kiemeney LA, Pedersen O, Kong A, Thorsteinsdottir U, Stefansson K 2009 Genome-wide association yields new sequence variants at seven loci that associate with measures of obesity. Nat Genet 41:18-24

6. Sankaranarayanan K, Chakraborty R, Boerwinkle EA 1999 Ionizing radiation and genetic risks. VI. Chronic multifactorial diseases: a review of epidemiological and genetical aspects of coronary heart disease, essential hypertension and diabetes mellitus. Mutat Res 436:21-57

7. Munroe PB, Caulfield MJ 2000 Genetics of hypertension. Curr Opin Genet Dev 10:325-329

8. Wallace C, Xue MZ, Newhouse SJ, Marcano AC, Onipinla AK, Burke B, Gungadoo J, Dobson RJ, Brown M, Connell JM, Dominiczak A, Lathrop GM, Webster J, Farrall M, Mein C, Samani NJ, Caulfield MJ, Clayton DG, Munroe PB 2006 Linkage analysis using co-phenotypes in the BRIGHT study reveals novel potential susceptibility loci for hypertension. Am J Hum Genet 79:323-331

9. Pravenec M, Petretto E 2008 Insight into the genetics of hypertension, a core component of the metabolic syndrome. Curr Opin Clin Nutr Metab Care 11:393-397

10. Talmud PJ 2001 Genetic determinants of plasma triglycerides: impact of rare and common mutations. Curr Atheroscler Rep 3:191-199

11. Sandhu MS, Heald AH, Gibson JM, Cruickshank JK, Dunger DB, Wareham NJ 2002 Circulating concentrations of insulin-like growth factor-I and development of glucose intolerance: a prospective observational study. Lancet 359:1740-1745

12. Hunt KJ, Lukanova A, Rinaldi S, Lundin E, Norat T, Palmqvist R, Stattin P, Riboli E, Hallmans G, Kaaks R 2006 A potential inverse association between insulin-like growth factor I and hypertension in a cross-sectional study. Ann Epidemiol 16:563571

13. O'Dell SD, Miller GJ, Cooper JA, Hindmarsh PC, Pringle PJ, Ford H, Humphries SE, Day INM 1997 ApaI polymorphism in insulin-like growth factor II (IGF2) gene and weight in middle-aged males. Int J Obes Relat Metab Disord 21:822-825

14. Gaunt TR, Cooper JA, Miller GJ, Day INM, O'Dell SD 2001 Positive associations between single nucleotide polymorphisms in the IGF2 gene region and body mass index in adult males. Hum Mol Genet 10:1491-1501

15. Gu D, O'Dell SD, Chen XH, Miller GJ, Day IN 2002 Evidence of multiple causal sites affecting weight in the IGF2-INS-TH region of human chromosome 11. Hum Genet 110:173-181
16. Zhang W, Maniatis N, Rodriguez S, Miller GJ, Day IN, Gaunt TR, Collins A, Morton NE 2006 Refined association mapping for a quantitative trait: weight in the H19-IGF2-INS-TH region. Ann Hum Genet 70:848-856

17. Le Stunff C, Fallin D, Bougnères $P 2001$ Paternal transmission of the very common class I INS VNTR alleles predisposes to childhood obesity. Nat Genet 29:96-99

18. Roth SM, Schrager MA, Metter EJ, Riechman SE, Fleg JL, Hurley BF, Ferrell RE 2002 IGF2 genotype and obesity in men and women across the adult age span. Int J Obes Relat Metab Disord 26:585-587

19. Rodríguez S, Gaunt TR, O'Dell SD, Chen XH, Gu D, Hawe E, Miller GJ, Humphries SE, Day IN 2004 Haplotypic analyses of the IGF2-INS-TH gene cluster in relation to cardiovascular risk traits. Hum Mol Genet 13:715-725

20. Kadlecovà M, Dobesovà Z, Zicha J, Kunes J 2008 Abnormal Igf2 gene in Prague hereditary hypertriglyceridemic rats: its relation to blood pressure and plasma lipids. Mol Cell Biochem 314:37-43

21. Ukkola O, Sun G, Bouchard C 2001 Insulin-like growth factor 2 (IGF2) and IGF-binding protein 1 (IGFBP1) gene variants are associated with overfeedinginduced metabolic changes. Diabetologia 44:2231-2236

22. Santoro N, Miraglia del Giudice E, Cirillo G, Raimondo P, Corsi I, Amato A, Grandone A, Perrone L 2004 An insertional polymorphism of the proopiomelanocortin gene is associated with fasting insulin levels in childhood obesity. J Clin Endocrinol Metab 89:4846-4849

23. Tanner JM, Whitehouse RH 1976 Clinical longitudinal standards for height, weight, height velocity, weight velocity, and stages of puberty. Arch Dis Child 51:170-179

24. Rolland-Cachera MF, Cole TJ, Sempé M, Tichet J, Rossignol C, Charraud A 1991 Body mass index variations: centiles from birth to 87 years. Eur J Clin Nutr 45:13-21

25. Wuhl E, Witte K, Soergel M, Mehls O, Schaefer F; German Working Group on Pediatric Hypertension 2002 Distribution of 24-h ambulatory blood pressure in children: normalized reference values and role of body dimension. J Hypertens 20:1995-2007

26. Heude B, Ong KK, Luben R, Wareham NJ, Sandhu MS 2007 Study of association between common variation in the insulin-like growth factor 2 gene and indices of obesity and body size in middle-aged men and women. J Clin Endocrinol Metab 92:2734-2738

27. O'Dell SD, Bujac SR, Miller GJ, Day IN 1999 Associations of IGF2 ApaI RFLP and INS VNTR class I allele size with obesity. Eur J Hum Genet 7:821-827

28. Gomes MV, Soares MR, Pasqualim-Neto A, Marcondes CR, Lôbo RB, Ramos ES 2005 Association between birth weight, body mass index and IGF2/ApaI polymorphism. Growth Horm IGF Res 15:360-362

29. Sayer AA, Syddall H, O'Dell SD, Chen XH, Briggs PJ, Briggs R, Day IN, Cooper C 2002 Polymorphism of the IGF2 gene, birth weight and grip strength in adult men. Age Ageing 31:468-470

30. Sahu A, Dube MG, Phelps CP, Sninsky CA, Kalra PS, Kalra SP 1995 Insulin and insulin-like growth factor II suppress neuropeptide $\mathrm{Y}$ release from the nerve terminals in the paraventricular nucleus: a putative hypothalamic site for energy homeostasis. Endocrinolgy 136:5718-5724

31. Santoro N, Del Giudice EM, Grandone A, Marzuillo P, Cozzolino D, Di Salvo G, Pacileo G, Calabrò R, Perrone L 2008 Y2 receptor gene variants reduce the risk of hypertension in obese children and adolescents. J Hypertens 26:1590-1594

32. Lucassen AM, Julier CJ, Beressi JP, Boitard C, Froguel P, Lathrop M, Bell J 1993 Susceptibility to insulin dependent diabetes mellitus maps to a $4.1 \mathrm{~kb}$ segment of DNA spanning the insulin gene and associated VNTR. Nat Genet 4:305-310

33. Rodenburg RJ, Teertstra W, Holthuizen PE, Sussenbach JS 1995 Postnatal liverspecific expression of human insulin-like growth factor-II is highly stimulated by the transcriptional activators liver-enriched activating protein and CCAAT/enhancer binding protein-alpha. Mol Endocrinol 9:424-434

34. Holthuizen P, Van Dijk MA, Rodenburg RJ, Koonen-Reemst AM, Sussenbach JS 1993 Transcriptional regulation of the major promoters of the human IGF-II gene. Mol Reprod Dev 35:391-393

35. Ruiz Pons M, García Nieto V, García MG, García Mérida M, Valenzuela Hdez C, Aguirre-Jaime A 2008 Reduced nocturnal systolic blood pressure dip in obese children. Nefrologia 28:517-524

36. Miraglia del Giudice E, Santoro N, Cirillo G, Raimondo P, Grandone A, D'Aniello A, Di Nardo M, Perrone L 2004 Molecular screening of the ghrelin gene in Italian obese children: the Leu72Met variant is associated with an earlier onset of obesity. Int J Obes Relat Metab Disord 28:447-450 